\title{
MODERNIZACJA ADMINISTRACJI PUBLICZNEJ Z PERSPEKTYWY OBSZARU METROPOLITALNEGO ${ }^{1}$
}

Od przełomu XX i XXI w. doświadczamy zasadniczych zmian praktycznie w każdej dziedzinie życia. Dochodzi do dynamizacji otoczenia głównie za sprawą postępu technologicznego i technicznego, co potwierdza nieustanny proces globalizacji świata. Pojawiają się nowe trendy², które z racji swojej masowości zmuszają większość podmiotów do dostosowania się do nowo powstałych warunków. Inaczej przez bierność i brak elastyczności zmniejszają swoją efektywność, co często prowadzi do ich marginalizacji, a czasami wręcz likwidacji. W sektorze prywatnym taka pasywna postawa przejawia się zazwyczaj trendem spadkowym choćby w sprzedaży, a nawet bankructwem. W sektorze publicznym zaś instytucja czy organ stają się mniej akceptowane przez społeczeństwo, a obszar, którym zarządzaja, traci atrakcyjność i w końcowym efek-

${ }^{1}$ Zastosowanie pojęcia „obszar metropolitalny” zamiast „metropolia” czy „aglomeracja” nie jest przypadkowe i za jego użyciem przemawiają: większy obszar definicyjny i bardziej zaawansowany charakter. Po pierwsze, mentalna modernizacja administracji publicznej powinna obejmować możliwie największą liczbę podmiotów publicznych, bez względu na ich zasięg i wielkość. W przypadku urzeczywistniania wizji metropolii istotna (priorytetowa) rolę odgrywają jednostki samorządu terytorialnego. Po drugie, „każdy obszar metropolitalny jest aglomeracja (lub zespołem miejskim), jednak nie każda aglomeracja (lub zespół miejski) spełnia warunki, aby zakwalifikować ja jako obszar metropolitalny. Aglomeracje (konurbacje) moga, ale nie muszą stać się metropoliami (obszarami metropolitalnymi), które stanowią kolejny etap rozwoju wielkich ośrodków miejskich, przy czym podstawą takiego przekształcenia są zmiany o charakterze jakościowym, a nie ilościowym, a zwłaszcza: zaawansowane przemiany urbanizacyjne oraz procesy integracji funkcjonalno-przestrzennej; wykształcenie (zagnieżdżenie) się funkcji metropolitalnych; procesy globalizacji i umiędzynarodowienia gospodarki (zachodzace pod wpływem postępu w technologiach informacyjnych); stworzenie spójnego systemu planowania i zarządzania. Należy pamiętać, że rozrost przestrzenny i demograficzny aglomeracji nie jest warunkiem wystarczającym do przekształcenia jej w metropolię lub obszar metropolitalny, zaś podstawowym wyróżnikiem metropolitalności jest międzynarodowa ranga układu osadniczego" - T. Markowski, T. Marszał, Metropolie, obszary metropolitalne, metropolizacja. Problemy i pojęcia podstawowe, Warszawa 2006, s. 17.

${ }^{2}$ Konkurencyjność na poziomie globalnym wymusza koncentrowanie kapitału, ograniczanie kosztów i w polskich realiach proces ten objawia się głównie w postaci kumulowania inwestycji wokół kilku ośrodków o dobrym położeniu geostrategicznym, usadowionych często przy wybranych miastach wojewódzkich. W skrócie można ten trend sprowadzić do zdania: „Nowatorstwo jakościowe [źródło konkurencyjności - dop. M.M.] polega na maksymalnym podnoszeniu jakości oferty przy jednoczesnym obniżaniu kosztów własnych" - K. Marciniec, Właściwe zarzqdzanie pierwszym krokiem do sukcesu, w: Nowoczesne instrumenty zarzqdzania w samorzadzie terytorialnym, Sulechów 2004, s. 33. 
cie wyludnia się $e^{3}$. Obecnie jednak aktywne jednostki, niestety stanowiące zdecydowaną mniejszość w polskim społeczeństwie, nauczyły się wykorzystywać narzędzia dane przez globalizację do wywierania presji na decydentów, szczególnie lokalnych, aby reagowali na zmiany otoczenia ${ }^{4}$. Dzieje się tak dlatego, że społeczeństwa w cywilizacji zachodniej, w coraz większej skali, stają się bardziej świadome i - co ważne - bardziej wymagajace, a dzięki środkom masowego przekazu efektywne w wymuszaniu takich działań, które zaspokajaja społeczne żądania. Ten proces w polskiej rzeczywistości ożywił się szczególnie w ostatnich latach głównie z dwóch powodów: zdecydowana większość społeczeństwa, a szczególnie społeczność aglomeracyjna, stała się częścią społeczeństwa informacyjnego i społeczeństwa ryzyka, co pociagnęło za sobą zawiązanie się potrzeby kompleksowego minimalizowania ryzyka. Jeśli władza chce być akceptowana społecznie i synergicznie z obywatelami realizować skomplikowane zadania (związane z rozwojem metropolitalnym), to musi wyjść naprzeciw tej potrzebie, ale to wymaga systematycznej mentalnej modernizacji administracji publicznej ${ }^{5}$. Ten problem interesująco przedstawia się w obliczu minimalizowania ryzyka na obszarze aglomeracji, na którym rodzą się ambicje metropolitalne, kiedy zadania muszą być koordynowane wielowymiarowo, wymagaja współpracy ościennych jednostek samorządu terytorialnego i przede wszystkim dotyczą ponadmilionowej, często różnorodnej, populacji.

\footnotetext{
${ }^{3}$ Już na wstępie należy zaznaczyć, że „podstawy zarządzania w sektorze prywatnym i publicznym sa podobne i widoczna jest silna tendencja do zbliżania się zasad funkcjonowania organizacji publicznych do jednostek prywatnych, szczególnie w zakresie efektywności i ekonomiki działalności organizacji publicznych. Jednakże różnice dotyczące własności, sposobów finansowania oraz motywów działania są tak znaczące, że zarząadzanie jednostkami sektora publicznego staje się odrębnym i autonomicznym obszarem badań naukowych oraz zastosowania instrumentów zarządzania jednostkami prywatnymi dopiero po odpowiednim ich zaadoptowaniu" - T. Dziurbejko, Planowanie rozwoju gminy jako instrument pozyskiwania funduszy pomocowych Unii Europejskiej, Warszawa 2006, s. 51.

${ }^{4}$ Początek XXI w. charakteryzuje się nierównomiernym wzrostem, rozdźwiękiem między centrum a peryferiami. To pierwsze sprowadza się głównie do miejsc z wykształconą siecią powiązań charakterystycznych dla współczesnych metropolii (aglomeracji). „Rozwój tych obszarów możliwy jest dzięki współpracy pomiędzy różnymi podmiotami, wśród których następuje przepływ ludzi, kapitału, towarów i usług. $\mathrm{W}$ procesie tym istotną rolę odgrywają samorządy, które nie tylko kreują warunki dla działalności podmiotów gospodarczych, organizacji pozarządowych, a także mieszkańców, ale i coraz częściej dostrzegają i rozumieją korzyści płynące z partycypacyjnego zarządzania publicznego (ang. public governance)" - J. Nowak, A. Perska, Sieć partnerstwa jako czynnik kształtowania się metropolii na przyktadzie aglomeracji poznańskiej, w: A. Kołomycew, B. Kotarba (red.), Zarzadzanie w samorzadzie terytorialnym, Rzeszów 2012, s. 412.

${ }^{5}$ Mentalna modernizacja oznacza systematyczne dopasowanie do oczekiwań społecznych pod względem mentalnym (przez całość przekonań, postaw, poglądów i sposobu myślenia) administracji publicznej rozumianej jako, zgodnie ze stanowiskiem H. Izdebskiego i M. Kuleszy, zespół działań, czynności i przedsięwzięć organizatorskich i wykonawczych prowadzonych na rzecz realizacji interesu publicznego przez różne podmioty, organy i instytucje na podstawie ustawy i w określonych prawem formach lub system złożony z ludzi, zorganizowany w celu stałej i systematycznej skierowanej ku przyszłości realizacji dobra wspólnego jako misji publicznej polegającej głównie (choć nie wyłącznie) na bieżącym wykonywaniu ustaw, wyposażonych w tym celu we władztwo państwowe oraz środki materialno-techniczne. Zastosowany termin (administracja publiczna) powinien być tak właśnie rozumiany, ponieważ nie można ograniczać mentalnej modernizacji tylko do stricte przedstawicieli administracji publicznej, czyli przedstawicieli władz publicznych czy kadry administracyjnej (urzędniczej).
} 


\section{SPOLECZEŃSTWO INFORMACYJNE I SPOŁECZEŃSTWO RYZYKA}

Zaawansowana globalizacja zmienia otoczenie, w którym funkcjonujemy, dynamizuje i jednocześnie komplikuje je, co szczególnie wyraźnie widać na przykładzie społeczeństw byłego bloku wschodniego. Ulegają one westernizacji i stopniowo uzależniają się od informacji, organizują wokół niej swoje życie zawodowe i prywatne. W konsekwencji nabywają cech społeczeństwa informacyjnego, w którym właśnie informację przeistoczona w dobro publiczne, podstawę naszego funkcjonowania, trzeba zdobywać, przetwarzać, przekazywać, kontrolować i ochraniać. Dzięki niej mieszkańcy byłych demokracji ludowych czuja się doinformowani, przeciwstawiaja się marginalizacji i przede wszystkim zwiększaja poczucie bezpieczeństwa, jakże ważne dla społeczeństwa ryzyka, którym także się stali6. Jednakże presja zwiększania zasobów informacyjnych, choć minimalizuje to ryzyko wystapienia zagrożeń, prowadzi także do niekontrolowanego wzrostu świadomości społeczeństwa. Elektroniczne środki przekazu dają dostęp praktycznie do każdych danych, redukują ograniczenia czasowe i przestrzenne, a więc stały się bezkosztowa platformą nadawania i odbierania komunikatów. Przecież portale społecznościowe czy komunikatory internetowe w zasadzie nie wymagaja nakładów, aby upublicznić na masowa skalę każdą informację. W takich warunkach trudno zarządzać gmina, a już z pewnością aglomeracja, nie mówiąc o obszarze metropolitalnym, szczególnie kiedy mass media działające na rynku medialnym nastawionym na zysk musza uatrakcyjnić każdy przekaz, co zwiększa ich oglądalność, ale jednocześnie prowadzi do rozprzestrzeniania się wiedzy, często opartej na półprawdach, która uzmysławia mnogość i tragizm zagrożeń oraz fałszywie uprawdopodabnia ich wystapienie ${ }^{7}$. W konsekwencji społeczeństwo indoktrynowane informacjami nasyconymi emocjami, w których niejednokrotnie pomija się czy przemilcza najważniejszy wymiar relacjonowanej wiadomości oraz nie przedstawia się pewnych ludzi czy ważnych problemów, staje się niezadowolone, zaniepokojone, niepewne i bojaźliwe. Takie oto społeczeństwo, działające $\mathrm{w}$ afekcie, zaczęło jednocześnie zwracać szczególną uwagę na bezpieczeństwo i przede wszystkim na zagrożenia ujawniane praktycznie

\footnotetext{
${ }^{6}$ Dzięki informacji uświadomili sobie zagrożenia, którym nieustannie podlegaja, oraz to, że „W zaawansowanej nowoczesności społeczna produkcja bogactwa idzie w parze ze społeczną produkcją ryzyka. W związku z tym problemy i konflikty dystrybucji społecznego niedostatku przysłonięte zostały przez problemy i konflikty, które powstają przy produkcji, definiowaniu i podziale ryzyka wytworzonego przez naukę i technikę" - U. Beck, Społeczeństwo ryzyka. W drodze do innej nowoczesności, Warszawa 2004, s. 27.

${ }^{7}$ Przecież niewiele osób potrafi krytycznie odnieść się do komunikatów, danych itp. „W erze informacyjnej można mówić o nadmiarze informacji, czy wręcz chaosie informacyjnym. Dlatego też tak istotną rolę stanowi pozyskanie umiejętności zbierania, gromadzenia, interpretacji, przetwarzania i dystrybucji informacji adekwatnie do zakładanych potrzeb" - J. Stępień, $Z a$ stosowanie symulacji konstruktywnej w procesie szkolenia podmiotów zarzqdzania kryzysowego, w: G. Sobolewski, D. Majchrzak (red.), Zarzadzanie kryzysowe w systemie bezpieczeństwa narodowego, Warszawa 2011, s. 442.
} 
w każdej dziedzinie życia. W tym miejscu należy podkreślić skomplikowany charakter wyzwań, szans, ryzyka i zagrożeń w procesie tworzenia obszarów metropolitalnych, które dotykają w głównej mierze aktorów publicznych, w tym samorządy. Te właśnie „budują osnowę stwarzająca lepsze lub gorsze warunki podmiotom z innych sektorów dla rozwoju aktywności sprzyjających rozwojowi aglomeracji miejskich w organizmy miejskie o charakterze metropolii"».

Obecnie postęp techniczny i technologiczny zredukował lub nawet zniósł ograniczenia czasowe i przestrzenne, stąd państwa, społeczeństwa i jednostki dla swojej ochrony zainteresowały się dotychczas ignorowanymi zagrożeniami. Przecież wielokrotnie, dzięki praktycznie bezkosztowej wymianie informacji, dowiadują się o przypadkach, w których niedużym nakładem sił można wywołać konsekwencje o zasięgu globalnym. Dostrzeżono, jak łatwo można właśnie w społeczeństwie ryzyka z najodleglejszych zakątków świata skutecznie pogorszyć warunki życia. W efekcie administracja publiczna odczuwa presję, aby ograniczyć społeczną wrażliwość na te łatwe do przeprowadzenia ataki. Poza tym jednostki zaczęły zwracać uwagę na bezpieczeństwo z szerszej perspektywy, już nie tylko tej militarnej, ale przede wszystkim pozamilitarnej (cywilnej). W skrócie i w wielkim uproszczeniu: chcemy być pewni, że po wyjściu z domu mamy gwarancję, że szczęśliwie do niego wrócimy. W związku z tym wszystko się atestuje, certyfikuje, homologuje, kontroluje, reguluje, szkoli, sprawdza lub ogranicza.

Powyższe objawy świadczą jednoznacznie o zawiązywaniu się w polskim społeczeństwie potrzeby kompleksowego minimalizowania różnych form ryzyka, czyli żądania poszukiwania potencjalnych zagrożeń praktycznie w każdej dziedzinie życia w celu ich identyfikacji i likwidacji. Można rzec, że nie wystarcza mu już pewność przetrwania i właściwie domaga się, choć w różnym stopniu, zabezpieczenia życia codziennego, a nawet poprawę jego jakości. Doszło do wyjątkowej sytuacji, od kiedy niezadowolenie społeczne sprowadza się do nieprawidłowego, odbiegającego od normy, zabezpieczenia ludności przed wszystkimi formami ryzyka, i to na najwyższym poziomie, często utożsamionym z pewną (stuprocentowa) ochroną. Powyższa problematyka nabiera istotnego znaczenia, od kiedy społeczeństwo polskie ulega trendowi koncentracji i przeistacza się w zbiorowość skupiającą się wokół aglomeracji o populacji przekraczającej często milion mieszkańców. Proces ten wydaje się nieodwracalny, tworzy niespotykane wcześniej trudności, którym podołać mogą jedynie współdziałające podmioty administracji publicznej ${ }^{9}$.

\footnotetext{
8 J. Nowak, A. Perska, op. cit., s. 413.

${ }^{9}$ Ze względu na priorytetową rolę samorządu terytorialnego należy podkreślić ponownie „konieczność postrzegania tego samorządu jako otwartej organizacji, w której różni interesariusze połączeni są luźnymi, niezhierarchizowanymi i dobrowolnymi powiązaniami. Istota jego działania nie jest bezpośrednie podejmowanie działań w postaci wytwarzania i dostarczania licznych usług publicznych, lecz tworzenie klimatu odpowiedniego do współpracy, która służy osiaganiu zróżnicowanych celów poszczególnych interesariuszy" - H. Gawroński, Zarzqdzanie strategiczne w samorzadach lokalnych, Warszawa 2010, s. 277.
} 


\section{MENTALNA MODERNIZACJA ADMINISTRACJI PUBLICZNEJ}

Przed administracją publiczna, a szczególnie samorządem terytorialnym, pojawił się nie lada problem: z jednej strony społeczeństwo chce uczestniczyć w atrakcyjnym przecież zglobalizowanym świecie pełnym zaawansowanej technologicznie rozrywki, a z drugiej - żąda od sektora publicznego usuwania wszelkich niebezpieczeństw, szczególnie nie akceptuje nowych rodzajów ryzyka. Problem polega na tym, że innowacje w tym samym czasie służą i szkodzą społeczeństwu, i tak z jednej strony digitalizacja, a szczególnie informatyzacja, umożliwia komunikację bez ograniczeń czasowych i przestrzennych, ale z drugiej - świat wirtualny stał się idealnym środowiskiem dla nietradycyjnych zagrożeń. W konsekwencji w połączeniu z wrażliwością charakterystyczną dla społeczeństw informacyjnych i społeczeństw ryzyka doprowadziło to do narzucenia administracji publicznej obowiązku zabezpieczenia życia codziennego pod każdym względem, od potencjalnych (mało prawdopodobnych) zdarzeń do nierozwiązywalnych problemów. Zakres tych działań rośnie niewspółmiernie do nakładów, co negatywnie oddziałuje na kondycję każdego państwa, zawsze przekracza jego możliwości. Nawet te bogate napotykają trudności, ponieważ adekwatnie do ich zasobów rosną także społeczne oczekiwania. Zależność ta dotyczy również szczebla regionalnego czy lokalnego, o czym świadczą różnorodne problemy poruszane przez instytucje i organy samorządu województwa, powiatu czy gminy. W zainteresowaniu pozostaja głównie szeroko rozumiane aspekty podnoszenia jakości i warunków życia, choć dochodza, zgodnie z idea kompleksowego działania, także rozproszone kwestie, jak integracja emigrantów, aktywizacja mieszkańców, wzmacnianie wspólnotowości, polepszanie szans rozwoju, zachowanie tożsamości kulturowej itp.

Niestety obecnie w polskiej praktyce kompleksowe minimalizowanie ryzyka sprowadza się do unowocześniania zasobów (sił i środków) oraz reorganizacji, np. przez transfer know-how. W związku z tym tworzy się kolejne urzędy, wydziały, komórki, zwiększa się ich zasoby (siły i środki) lub reorganizuje, co zasadniczo poprawia odbiór społeczny ${ }^{10}$. Jednak rzeczywistość pokazuje nam, że takie działanie nie wystarcza, a nawet szkodzi przez nałożenie na nieuregulowaną dotychczas dziedzinę życia często skostniałej prawem struktury administracyjnej. Okazuje się, że oprócz zasobów i organizacji istnieje coś jeszcze, co wpływa na efektywność sektora publicznego, a szczególnie na społeczny odbiór wdrażanych rozwiązań. Dzięki odniesieniu się do kultury bezpieczeństwa ${ }^{11}$ wiemy, że zaspokojenie społecznej potrzeby kompleksowe-

${ }^{10}$ Niemniej pojawia się pewna wątpliwość, która obecnie przerodziła się w spór między administracja centralną a samorządowa, czy do urzeczywistnienia wizji metropolii na obecnym (podstawowym) etapie w polskiej rzeczywistości potrzeba regulacji ustawowej, czy wystarczy odpowiednia mentalność władz lokalnych (decydentów) działających na zasadzie dobrych praktyk (wdrażanie rozwiązań najbardziej efektywnych i zrównoważonych minimalizujących ryzyko charakterystyczne dla obszarów metropolitalnych, np. problemy komunikacyjne, degradacja środowiska, negatywne skutki suburbanizacji).

${ }^{11} \mathrm{Z}$ jednej strony kultura bezpieczeństwa posiada pojemne znaczenie, dzięki czemu można zawrzeć w niej w praktyce szeroko pojmowaną i nieograniczoną obszarowo (wielodziedzinowa) po- 
go minimalizowania ryzyka oprócz zasobów i organizacji wymaga trzeciego (ostatniego) komponentu - mentalności. „Dopiero na gruncie pewnego poziomu kultury ogólnej można kształtować wymagany stosunek do obowiązków, do pracy, uczyć postrzegania norm technologicznych, troski o innych, harmonijnego współdziałania i dyscypliny. Mniejszą wagę przywiązywało się w naszej tradycji do takich niekulturalnych zachowań, jak bylejakość, dowolność, brak dyscypliny wykonawczej, mała staranność, niedbalstwo itp. Przejawy tych wad i nałogów zwykliśmy lekceważyć jako drobiazgi, elementy na pozór nieważne, rzeczy nieistotne. W sprawach bezpieczeństwa, powiedzmy to wyraźnie, drobiazgi na ogół tworzą najsłabsze ogniwo" ${ }^{12}$. W skrócie można rzec, że z punktu widzenia potrzeb i oczekiwań polskie społeczeństwo upodobniło się do Zachodu, ale odróżnia się wysokim poziomem uzależnienia od państwa oraz brakiem odpowiedzialności za własne czyny. W tym miejscu warto postawić pytanie: W jaki sposób mentalność wpływa na zaspokojenie potrzeby kompleksowego minimalizowania ryzyka mieszkańców aglomeracji będących jednocześnie częścią społeczeństwa informacyjnego i społeczeństwa ryzyka w dobie kształtowania się obszarów metropolitalnych w Polsce?

W takim społeczeństwie egzystujacym w zglobalizowanym świecie, gdzie jego świadomość nie nadąża za postępem technicznym i technologicznym, istotną rolę odgrywa szybkość i elastyczność reagowania na niespotykane wcześniej wielowątkowe szanse, wyzwania, ryzyko i zagrożenia. W głównej mierze chodzi o to, aby administracja publiczna (szczególnie samorząd) działała kompleksowo ${ }^{13}$, a więc nie można pozwolić na to, aby w wybranym obszarze, nawet tym niewielkim, ale znaczącym dla społeczeństwa, pojawiło się poczucie opieszałości czy - co gorsza - ignorowania problemu, a to wymaga kompetencji sprzyjajaccych autonomii w działaniu, szczególnie na niższych (lokalnych) szczeblach. Przecież to „polityka lokalna wpływa bezpośrednio na warunki życia, tworzac ramy prawne, finansowe i organizacyjne, w których funkcjonuje społeczność lokalna, a pośrednio - na jakość życia, definiowana przez subiektywne odczucia mieszkańców"14. W konsekwencji znaczenia lo-

trzebę kompleksowego minimalizowania ryzyka. Sprowadza się ją (kulturę) do „sposobu postrzegania wyzwań, szans i zagrożeń, sposobu myślenia o bezpieczeństwie oraz sposobu odczuwania jego braku, a także sposobu zapewnienia bezpieczeństwa” - M. Cieślarczyk, Tożsamość służb reagowania kryzysowego w świetle socjologicznego modelu kultury bezpieczeństwa, w: J. Maciejewski, W. Nowosielski (red.), Tożsamość społeczna grup dyspozycyjnych, Wrocław 2009, s. 44. Z drugiej strony umożliwia ona porządkowanie przedmiotu badań (powyższej potrzeby) według jej trzech komponentów: zasobów, organizacji i mentalności.

${ }^{12}$ S. Kwiatkowski, A. Kwiatkowska-Drożdż, O bezpieczeństwie obywateli i zarzqdzaniu kryzysowym, Tyczyn 2005, s. 65.

${ }^{13}$ Pojawia się tutaj problem współdziałania samorządu na różnych poziomach (gminnym, powiatowym i wojewódzkim) z administracją państwowa, organizacjami pozarządowymi, a nawet samymi mieszkańcami. Do kluczowych przeszkód związanych z urzeczywistnianiem wizji metropolii zaliczyć można: egoizm wybranych samorządów, przestarzałe prawo, mało efektywna wymiana informacji i przede wszystkim niechęć ograniczania własnego władztwa. Bardziej szczegółowe problemy udało się uwidocznić na przykładzie Metropolii Poznań. Zob. szerzej: J. Nowak, A. Perska, op. cit., s. 422 .

${ }^{14}$ G. Masik, Wpływ polityki lokalnej na warunki i jakość życia. Przyktad strefy suburbanizacji Trójmiasta, Warszawa 2010, s. 13. 
kalnej władzy w procesie metropolizacji (jej kompleksowego działania) okazuje się, że wprowadzenie i zacieśnienie horyzontalnych i wertykalnych zależności ${ }^{15}$ pomiędzy podmiotami sektora publicznego i prywatnego wymusza zmianę mentalności biernej na aktywną ${ }^{16}$. Zatem docelowo osoby zajmujace decyzyjne stanowiska publiczne powinny charakteryzować się mentalnościa menedżera ${ }^{17}$. Takie jednostki staną się odpowiedzialne, przewidywalne oraz zdolne do kalkulacji, strategicznego myślenia i przede wszystkim współpracy, co prowadzi do maksymalizacji korzyści, kiedy wnikliwie obserwuje się rozwój społeczności, aby w porę rozpoznać potencjalne lub już istniejacce, choć ukryte, zagrożenia. Należy kłaść szczególny nacisk w procesie mentalnej modernizacji administracji publicznej właśnie na współpracę ${ }^{18}$. Po pierwsze, jak wcześniej wspomniano, instytucje i organy nie mają możliwości rozwiazywania w pojedynkę problemów wynikających z tworzenia się obszaru metropolitalnego, a nawet już aglomeracyjnego. Po drugie, tylko przy pożądanej współpracy uda się zarządzać strategicznie, czyli optymalnie monitorować zmienne warunkujące tworzenie metropolii ${ }^{19}$. Co więcej, propagowane współdziałanie będzie skuteczne wtedy, kiedy osiagnie się taką mentalność, która ukierunkuje wysiłki władz lokalnych i współpracujaccych z nimi pozostałych podmiotów z układów rywalizacyjnych na powiązania kooperacyjne. Zatem tylko kompleksowe określenie wrażliwości lokalnej społeczności na różne formy ryzyka prowadzi do całościowego poznania oczekiwań tej grupy, co nie pozostaje obojętne na późniejszą ocenę obszaru metropolitalnego. Inaczej strategie indywidualne staną się niebezpieczne, ponieważ nie będą odnosiły się do zbioru pozostałych,

${ }^{15}$ Zasadniczą rolę w kształtowaniu obszarów metropolitalnych odgrywa współpraca w ramach partnerstwa publiczno-prywatnego opartego na zasadzie synergii, „na podstawie której buduje się współpracę oznaczającą wzajemne oddziaływanie na siebie funkcji publicznych i komercyjnych oraz przenikanie się rezultatów ich wspólnej pracy” - M. Moszoro, Partnerstwo publiczno-prywatne w sferze użyteczności publicznej, Warszawa 2010, s. 227.

${ }^{16}$ Bierność sprowadza się do tego, że problemy rozwiązuje się wtedy, kiedy staną się dokuczliwe dla większej społeczności lub wystarczająco zostaną nagłośnione przez mass media, co w dobie społeczeństwa ryzyka, społeczeństwa informacyjnego wydaje się archaiczną postawa. Natomiast mentalność aktywna przejawia się głównie przewidywaniem oraz prewencyjnym myśleniem (działaniem).

${ }^{17} \mathrm{~W}$ tym miejscu warto dodać, że „podstawą osiagnięcia celów jakościowych w działalności urzędu samorządu terytorialnego jest między innymi sprawny system przygotowania i doskonalenia pracowników. Pojawia się potrzeba zatrudniania pracowników o wiedzy i umiejętnościach związanych z zarządzaniem i organizowaniem usług, zarządzaniem projektami, promocją, utrzymywaniem kontaktów z mediami, prowadzeniem analiz itd.” - J. Mielżyński, Jakość pracy i kadr administracji samorzadu terytorialnego, w: Nowoczesne instrumenty zarzadzania w samorzadzie terytorialnym, s. 79.

${ }^{18}$ Docelowo mentalność powinna sprzyjać kompleksowemu współdziałaniu wszystkich szczebli administracji publicznej i pożądanemu dla obszarów metropolitalnych zarządzaniu poprzez „planowanie działań, ich organizowanie, motywowanie ludzi oraz kontrolę realizowanej działalności” - S. Sudoł, Nauki o zarzadzaniu, Warszawa 2012, s. 31.

19 „Istotą zarządzania strategicznego jest kompleksowe koordynowanie projektami w obliczu zmiany. W zasadzie nadrzędnym celem tych działań jest stałe poszukiwanie rozwiązań o charakterze adaptacyjnym, dostosowującym i uwzględniającym możliwie jak największą liczbę ważonych parametrów. Oznacza to, że zarządzanie strategiczne mając walor aplikacyjny jest traktowane szerzej - jako działanie zakładające wywołanie kolejnych zmian w bliższym i dalszym otoczeniu, w bliższej i dalszej perspektywie”. Zob. R. Wiszniowski, Zintegrowane zarzadzanie strategiczne rozwojem państwa. Doświadczenia polskie, Toruń 2013, s. 13. 
np. sasiednich gmin czy powiatów. Przykładowo dochodzi do przesadnej rozbudowy obiektów użyteczności publicznej na niewielkim obszarze, np. kilku pobliskich gmin, dotyczy to szczególnie basenów, term, ośrodków sportowo-rekreacyjnych. W konsekwencji taka rywalizacja, oparta najczęściej na ambicjach lokalnych decydentów, prowadzi do przesycenia tej części sektora usług i niskiej opłacalności (także społecznej), nie mówiąc już o rentowności.

\section{WNIOSKI}

Realizowane w ramach potrzeby kompleksowego minimalizowania ryzyka coraz bardziej skomplikowane i rozległe zadania przerosły możliwości jednostek, a to uzależniło je od administracji publicznej. Ograniczanie nowych postaci ryzyka, szczególnie tych wynikających z metropolizacji, wymaga zaangażowania potencjału przypisanego państwu i samorządom, które posiadaja kompetencje do tego rodzaju działań i przede wszystkim aparat przymusu do masowej akumulacji zasobów. Poza tym zakres obowiąkowej ochrony narzucanej przez społeczeństwo przybiera rozmiary przerastające poszczególne instytucje i organy, stąd część z nich musi współdziałać horyzontalnie i wertykalnie w ramach administracji terenowej, samorządu, a nawet podmiotów prywatnych ${ }^{20}$. Obecnie, zgodnie z potrzeba kompleksowego minimalizowania ryzyka, społeczeństwo (a szczególnie mieszkańcy aglomeracji) chce pozbyć się wszelkich niebezpieczeństw z życia codziennego, tak jak się mu wydaje, że pozbyło się zagrożeń militarnych. Problem pojawia się wtedy, gdy zasoby publiczne nie pozwalają na spełnienie tych kosztownych oczekiwań, dochodzi do zahamowania procesów rozwojowych, co głównie objawia się spowolnieniem gospodarczym i redukcją konsumpcjonizmu. $\mathrm{Z}$ tego punktu widzenia, atrakcyjnego przecież konsumpcyjnego stylu życia, w społeczeństwie ryzyka, społeczeństwie informacyjnym niedoskonałości hamujące koniunkturę istotnie determinują zachowania jednostki ${ }^{21}$. Wtedy to narzuca się wręcz administracji publicznej, bez względu na jej szczebel (zasięg administracyjny), pewne działania, takie, które sa zgodne z oczekiwaniami coraz bardziej świadomego społeczeństwa ${ }^{22}$. Inaczej, kiedy potrzeby społeczne są nierealizowane - poja-

\footnotetext{
${ }^{20}$ Podmioty prywatne, działające w ramach partnerstwa publiczno-prywatnego, wraz z najniższym szczeblem administracji publicznej odgrywają zasadniczą rolę, ponieważ to one stykaja się bezpośrednio ze społecznością lokalną i ostatecznie wpływają na sukces lub porażkę wdrażanych rozwiązań.

${ }^{21}$ Potwierdza się wcześniejsze spostrzeżenie, że „zamiast biernego administrowania (w ramach procedur niezwiązanych z rzeczywistością gospodarcza) potrzebne jest aktywne zarządzanie (ukierunkowanie działań na zjawiska rynkowe)" - T. Lubińska et al., Reformy budżetowe w zakresie nowego zarzadzania publicznego, w: eadem (red.), Nowe zarzqdzanie publiczne - skuteczność i efektywność, Warszawa 2009, s. 29.

${ }^{22}$ Warto przytoczyć wyraźnie sformułowane powtórzenia o istocie idei powołania obszaru metropolitalnego. „Tylko zintegrowane podejście może w dużej mierze zwiększać zdolność do czerpania zrównoważonych korzyści. By rozwój był trwały i zrównoważony, musi więc być zintegrowany. Trwały, zrównoważony rozwój społeczno-gospodarczy jest możliwy tylko w zintegrowanych i racjonalnie zorganizowanych wielopodmiotowych układach" - M. Słodowa-Hełpa, Samorzqd terytorialny w procesie stymulowania zintegrowanego rozwoju, w: A. Kołomycew, B. Kotarba (red.), op. cit., s. 306-307.
} 
wia się niezadowolenie z władzy i spada do niej zaufanie, szczególnie kiedy strategiczne cele związane z rozwojem obszaru metropolitalnego, wcześniej aglomeracyjnego, nie pokrywają się z nadziejami jego mieszkańców i nie spełniaja ich potrzeb. W takich warunkach utrzymanie, akceptowalnego przez decydentów, poziomu zaufania społecznego wymaga systematycznej mentalnej modernizacji (uelastycznienia i aktywizacji) administracji publicznej, co umożliwi redukcję negatywnych konsekwencji społeczeństwa ryzyka i ograniczenie defektów społeczeństwa informacyjnego w dobie metropolizacji. Jeżeli nie dojdzie do zmian w tym trzecim (ostatnim) komponencie, to wysiłki czynione w dwóch pierwszych (zasobach i organizacji) okażą się niewystarczające w przyciagnięciu do zarządzanego obszaru metropolitalnego kapitału, nie tylko finansowego, ale także, jeśli nie przede wszystkim, ludzkiego ${ }^{23}$. Kończąc, należy jednoznacznie i wyraźnie zaznaczyć, że obiektywną oceną kompetencji administracji publicznej, szczególnie tej samorządowej na każdym szczeblu, będzie prosperity lub upadek zarządzanego przez nią obszaru metropolitalnego. Jeżeli działania nie będą odpowiadać potrzebie kompleksowego minimalizowania ryzyka zagrażającego jego mieszkańcom, będą oni wybierać atrakcyjniejsze miejsce, co doprowadzi do deprecjacji tego obszaru, administrowanego przez mentalnie archaiczną władzę.

dr Maciej Magiera

Uniwersytet im. Adama Mickiewicza w Poznaniu

maciej.magiera@amu.edu.pl

\section{MODERNISATION OF PUBLIC ADMINISTRATION FROM THE POINT OF VIEW OF A METROPOLITAN AREA}

Sum mary

Mass participation in the attractions of the globalised world necessarily entails certain trends. One of them leads to the concentration of societies around large metropolitan areas, which forces the public administration, especially local government, to adopt pioneering steps. In the information society, the risk society undergoing the processes of metropolitanisation, the fulfilment of the social demand for comprehensive risk minimalisation requires the constant modernisation of the mentality of the public administration. Otherwise archaic governmental activity will lead to the depreciation of the area which it administrates

${ }^{23}$ Wydaje się, że w czasie aktualizacji w 2013 r. Strategii rozwoju Miasta Poznania do roku 2030 w mocno ograniczony sposób zainteresowano się trzecim komponentem - mentalnościa. W części poświęconej programom strategicznym, a dokładniej w ósmym (aktualnie szóstym) programie Metropolitalny Poznań, warto dopisać przy najbliższej aktualizacji do ryzyka realizacji planu brak kompatybilności (zgodności) mentalności administracji publicznej z ideą metropolitalna. Wielce prawdopodobne może być to, że to właśnie archaiczna mentalność części sektora publicznego stanie się głównym czynnikiem hamującym osiagnięcie celu strategicznego tego programu. Zatem warto byłoby w ramach monitoringu strategicznego analizować, czy ten problem nie stanowi większego wyzwania niż, zapisane już w strategii, niekontrolowane procesy deglomeracyjne, brak woli współpracy gmin tworzących obszar metropolitalny, brak rozwiązań prawnych stymulujących zrównoważony rozwój aglomeracji czy brak przepisów prawnych regulujących status metropolii w Polsce (rodzaje ryzyka wyszczególnione przez autorów na stronie 160 Strategii). 
